Canadian Journal of Fisheries and Aquatic Sciences

Canadian

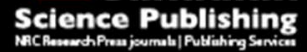

Journal canadien des sciences halieutiques et aquatiques

\title{
Relative effects of biotic and abiotic factors during early life history on recruitment dynamics: A case study
}

\begin{tabular}{|r|l|}
\hline Journal: & Canadian Journal of Fisheries and Aquatic Sciences \\
\hline Manuscript ID & cjfas-2016-0155.R1 \\
\hline Manuscript Type: & Article \\
\hline Complete List of Authors: & $\begin{array}{l}\text { Zhang, Fan; University of Guelph, Integrative Biology } \\
\text { Reid, Kevin; University of Guelph, Department of Integrative Biology; } \\
\text { Ontario Commercial Fisheries' Association, } \\
\text { Nudds, Thomas; University of Guelph, Department of Integrative Biology }\end{array}$ \\
\hline Keyword: & $\begin{array}{l}\text { RECRUITMENT < General, ENVIRONMENTAL EFFECTS < General, TROPHIC } \\
\text { RELATIONSHIPS < General, PERCID SPECIES < Organisms, INLAND } \\
\text { FISHERIES < General }\end{array}$ \\
\hline & \\
\hline
\end{tabular}

SCHOLARONE $^{\text {m }}$

Manuscripts 
1 Relative effects of biotic and abiotic factors during early life history on

2 recruitment dynamics: A case study

$3 \quad *$ Fan Zhang $^{1}$, Kevin B. Reid ${ }^{1,2}$, Thomas D. Nudds ${ }^{1}$

$4 \quad *$ Corresponding author: fzhang02@uoguelph.ca

5 1. Department of Integrative Biology, University of Guelph, 50 Stone Road East, Guelph, ON, $6 \quad \mathrm{~N} 1 \mathrm{G} 2 \mathrm{~W} 1$

7 2. Ontario Commercial Fisheries' Association, 45 James Street, Blenheim, ON, N0P 1A0 


\section{Abstract}

The relative effects of biotic and abiotic factors, and the life-history stages upon which

11 they act to affect fish recruitment, vary among species and ecosystems. We compared the

12 effects of spawning stock biomass, and factors operating at early-term (encompassing the egg,

13 yolk-sac larval and first few days of swim-up larval stages), middle-term (including the swim-

14 up larval and pelagic juvenile stages) and late-term (over the benthic juvenile stage) on

15 recruitment by yellow perch (Perca flavescens) in the western basin of Lake Erie between

161999 and 2013. Variation of recruitment was mainly driven by middle-term effects. Then,

17 abiotic factors, such as warming rate and wind speed, more strongly affected recruitment than

18 did biotic factors. Among middle-term biotic factors, the top-down effect of yearling walleye

19 abundance was stronger than the bottom-up effect of zooplankton abundance. Similar to

20 marine species, physical processes appear to strongly affect recruitment dynamics of Lake

21 Erie yellow perch over its pelagic larval and juvenile stages, demonstrating the importance of

22 physical and biological processes in understanding fish population dynamics in large lakes.

23 Keywords: recruitment mechanism, trophic interaction, physical process, yellow perch, Lake

24 Erie 


\section{Introduction}

27

28

29

30

31

32

Recruitment to adult fish populations is determined by complex ecological processes acting on multiple early life-history stages (Houde 2008; Pepin 2015). The life-history stage during which year-class strength is established varies by species and ecosystems, but typically occurs during the first year after spawning, including egg, larval (encompassing the yolk-sac and swim-up larval stages) and early-juvenile life-history stages (Bradford 1992; Houde 1994). Recruitment theories emphasize alternative views about the relative importance of different ecological processes that act on different life-history stages to determine year-class strength. The "stock-recruitment" hypothesis emphasizes density-dependent effects of spawning stock size on subsequent recruitment (Myers and Barrowman 1996). The "critical period" and "match-mismatch" hypotheses emphasize feeding success during the larval stage, as affected by prey availability during the first few days of the swim-up larval stage, i.e. the first-feeding period (Hjort 1914), or the match, or lack thereof, between the timing of plankton production with fish reproduction (Cushing 1975). Alternatively, the "aberrant drift", "stable ocean", and "optimal window" hypotheses emphasize the effects of hydrodynamic conditions on larval and juvenile stages, whereby recruitment is determined by retention on, or transport to, favorable nursery areas (Hjort 1914; Begg and Marteinsdottir 2002) or favorable hydrological conditions for foraging (Lasker 1975; Cury and Roy 1989). Finally, the "growth-mortality" and "stageduration" hypotheses emphasize the importance of rapid growth during larval and juvenile stages, which can limit cumulative mortality through greater starvation tolerance and predator evasion or shortened critical stage durations for larger individuals (Anderson 1988; Pepin and Myers 1991). 
No single recruitment hypothesis universally explains fish recruitment dynamics, which indicates a need for an integrative approach that focuses on comparing and linking multiple hypotheses (Houde 2008; Hare 2014). The realization of ecosystem regime shifts (DeYoung et al. 2004; Lees et al. 2006) further implies that the relative importance of different ecological processes, as well as the life-history stages upon which they act, may change over time even for a single species in a given ecosystem (Bailey et al. 2005). It has become difficult to develop general theories about specific ecological processes which act on early life-history stages to drive fish recruitment. The context-specific nature of fish recruitment mechanisms argues for an integrative approach to evaluate evidence for multiple hypotheses for specific populations (Hare 2014).

Yellow perch (Perca flavescens) resemble many marine species with respect to their high fecundity, small egg size, and long pelagic larval stage (Pritt et al. 2014). Further, the hydrological conditions of large freshwater lakes approach those of marine environments, prompting the question: To what extent are factors influencing recruitment of freshwater yellow perch similar to factors known to be driving recruitment of marine fish species (Janssen et al. 2014; Ludsin et al. 2014)? Also, the geographic setting of the Laurentian Great Lakes ecosystem provides advantages over marine ecosystems, such as a relatively tractable spatial scale, accessibility for survey vessels and a semi-enclosed system, for systematic studies of fish recruitment (Ludsin et al. 2014; Pritt et al. 2014).

The availability of data from intensive surveys of biotic and abiotic conditions, together with abundant fisheries-dependent and -independent data about yellow perch in the western basin of Lake Erie, provides an opportunity to test among multiple recruitment hypotheses. We evaluated the weight of evidence among several potential mechanisms driving 
71 recruitment by yellow perch in the western basin of Lake Erie in four operationally defined

72 time periods based on yellow perch life history and the timing of data collection: 1) spawning,

73 between late-April and early-May; 2) the period from spawning through May, including the

74 egg, yolk-sac larval and the first few days of the swim-up larval stage (early-term); 3) the

75 period from June through August, mainly encompassing the swim-up larval and pelagic

76 juvenile stages (middle-term); and 4) the final benthic juvenile stage before maturing at age 2

77 (late-term) (Fig. 1). Specifically, we evaluated whether variation in recruitment by yellow

78 perch was driven by 1) spawning stock biomass (SSB) during spawning period; 2) prey

79 abundance, water temperature, wind speed and dissolved oxygen during the early-term; 3)

80 predator and prey abundances, water temperature, spring warming rate, wind speed and

81 dissolved oxygen during the middle-term; and/or 4) ecological processes acting during the

82 late-term.

\section{Methods}

84

Study area

Lake Erie is the shallowest of the five Laurentian Great Lakes, with a mean depth of $19 \mathrm{~m}$ and surface area over $25,000 \mathrm{~km}^{2}$ (Belore et al. 2014). The lake is surrounded by the province of Ontario and multiple U.S. states including Michigan, Ohio, Pennsylvania and New York. The high human population density and intensive agriculture in these regions makes Lake Erie the most heavily human influenced lake among the Great Lakes, and the lake has experienced substantial ecosystem changes due to eutrophication, phosphorus reduction, invasive species, e.g., Dreissenid mussels and round goby (Neogobius melanostomus), and fishing (Griffiths et al. 1991; Tyson and Knight 2001). As the most productive of the Great Lakes, Lake Erie supports several important fisheries, with yellow perch and walleye (Sander 
vitreus) being the largest (Belore et al. 2014; Wills et al. 2014). Lake Erie comprises eastern, central and western basins; the western basin is the most shallow (Fig. 2). The yellow perch fishery is assessed and managed on the basis of data collected across four management units (MUs), of which one is the western basin (Belore et al. 2014).

Yellow perch spawning stock size, recruitment, age-0 and age-1 juvenile densities Since 1975, the Yellow Perch Task Group (YPTG) has generated age-specific estimates of yellow perch abundance and biomass in the western basin of Lake Erie using statistical catch-at-age (SCAA) models for age classes 2- 6 (Belore et al. 2014). The fisherydependent data from commercial gillnet fishery and fishery-independent data from gillnet and trawling surveys were fit to the SCAA models for parameter estimation (Belore et al. 2014).

We indexed recruitment as the abundance of age- 2 fish in year $t$ from Belore et al. (2014), whereas parental stock size was indexed as the abundance of mature fish (age- 2 and older) in year t-2 from Belore et al. (2014). In Lake Erie, female yellow perch typically mature at age-2 to -4 (Sztramko and Teleki 1977). Therefore, we estimated annual percentages of mature age2 and -3 females using the Ontario Partnership Index Gillnet Survey co-conducted by Ontario Ministry of Natural Resources and Forestry (OMNRF) and Ontario Commercial Fisheries' Association (OCFA); females age-4 and older were assumed to be 100\% mature (D. Gíslason, unpubl. data). SSB was estimated as:

where, $S S B_{t}$ is the SSB in year $t, n$ is the number of age classes, $B_{a, t}$ is the biomass of age- $a$ fish in year $t, m_{a, t}$ is the proportion of mature fish of age- $a$ in year $t$, and 0.5 is the constant used to calculate the proportion of females assuming a 1:1 sex ratio for all age classes. 
An Interagency Index Trawling Survey (IITS), co-conducted by Ontario Ministry of

119

120

121

122

123

124

125

126

127

128

129

130

131

132

133

134

Natural Resources and Forestry (OMNRF), Ohio Department of Natural Resources (ODNR) and United States Geological Survey (USGS), has been undertaken in the western basin of Lake Erie each August since 1988 (Thomas et al. 2014). The IITS conducted about 74 trawls per year between 1988 and 2014; sampling effort varied little among years. The age-0 and age-1 yellow perch juvenile densities $\left(\right.$ No. $\left.\bullet \mathrm{ha}^{-1}\right)$ were estimated based on average catch-perunit-effort (CPUE) during each annual survey.

\section{Effects of SSB and late-term ecological factors}

To identify key life-history stages potentially influencing yellow perch year-class

strength, a Paulik diagram was used to test three step-wise correlations among log-transformed estimates of SSB in year $t$, age- 0 juvenile density in August in year $t$, age-1 juvenile density in August in year $t+1$, and estimates of age-2 recruitment in year $t+2$, between 1999 and 2013

(Nash 1998). The Pearson correlation coefficient was calculated to test the correlation significance. The coefficient of variation $(\mathrm{CV})$ was used to summarize relative annual variations in SSB, age-0 and ag-1 juvenile densities, and recruitment. All statistical calculations were implemented using version 2.15.0 R software ( $\mathrm{R}$ Development Core Team 2012).

If recruitment dynamics were strongly affected by SSB, all three pair-wise correlations should be significant. If variation of recruitment was mainly affected by late-term factors, the correlation between SSB and age-0 juvenile density should be strong, while either of the two other correlations should be weak. If the correlation between SSB and age-0 juvenile density was the weakest among the three correlations, we inferred that variation of recruitment was predominantly influenced by early-term and/or middle-term factors. 
141

142

143

144

145

146

147

148

149

150

151

152

153

154

155

156

157

158

159

160

161

162

163

Effects of early-term and middle-term factors

In the western basin of Lake Erie, adult yellow perch (age-2 and older) typically spawn in the near shore area between mid-April and early-June, depending on water temperature and photoperiod (Farmer et al. 2015), but the peak usually occurs between late-April and earlyMay (Henderson et al. 2000). The duration of the egg period is two to three weeks, with about three days between hatching and first-feeding, i.e. yolk-sac larval stage (Rose et al. 1999). Swim-up larvae start pelagic feeding by late-May, and transform to pelagic juveniles sometime in June. These juveniles shift from pelagic to benthic feeding sometime in July (most individuals will begin benthic feeding by August) depending on zooplankton availability and individual body size (Wu and Culver 1992). Physical factors, e.g., water temperature, warming rate, wind speed and dissolved oxygen, strongly influenced yellow perch survival during early life-history stages (Clady 1976; Henderson 1985; Farmer et al. 2015); biotic factors, e.g., predator and prey abundance, were also important factors affecting yellow perch year-class strength (Hartman and Margraf 1993; Dettmers et al. 2003).

We used average bottom water temperature, dissolved oxygen, wind speed and zooplankton density in May to indicate early-term effects of physical environment and prey availability. Average bottom water temperature, dissolved oxygen and wind speed from June through August were used to indicate effects of middle-term abiotic factors. The warming rate was measured by regressing bottom temperature on Julian date from April to June (Henderson and Nepszy 1988). Monthly average zooplankton density from June through August was used to represent a middle-term, bottom-up effect of prey abundance. Walleye and alewife (Alosa pseudoharengus) are two important predators of yellow perch in the Laurentian Great Lakes (Hartman and Margraf 1993; Mason and Brandt 1996; Shroyer and McComish 2000), so the 
164 middle-term, top-down effects of both walleye and alewife densities in August were also 165 included.

The Lower Trophic Level Assessment (LTLA) program in Lake Erie, initiated by the

167 Forage Task Group (FTG) of the Lake Erie Committee, has, annually since 1999, collected 168 data about water temperature $\left({ }^{\circ} \mathrm{C}\right)$, dissolved oxygen concentration $\left(\mathrm{mg} \bullet \mathrm{L}^{-1}\right)$, wind speed

$169\left(\mathrm{~km} \bullet \mathrm{h}^{-1}\right)$, and zooplankton density $\left(\mathrm{No} \cdot \mathrm{L}^{-1}\right)$, biweekly from April through September (Thomas 170 et al. 2014). Four stations were located in the western basin, and the mean values of bottom 171 water temperature, dissolved oxygen, wind speed, and zooplankton density were calculated 172 across stations and samples within each month between 1999 and 2013. Walleye and alewife 173 densities were estimated based on average catch-per-unit-effort (CPUE) during each annual 174 survey of IITS between 1999 and 2013 (Thomas et al. 2014); CVs of these early- and middle175 term factors were also calculated (Table 1).

176 Relative importance of early-term factors on year-class strength

177 We evaluated the relative importance of early-term ecological factors based on 178 stepwise contrasts among variants of the Ricker model (Zwolinski and Demer 2014), with age1790 juvenile density in August used as an index of yellow perch year-class strength (Farmer et al. 180 2015),

$$
J_{t}=\alpha S_{t} e^{-\beta S_{t}+\sum\left(\gamma_{i} E_{i, t}\right)+\varepsilon}(\text { Ricker-J) }
$$
where $J_{t}$ is the age-0 yellow perch juvenile density in year $t, S_{t}$ is the spawning stock biomass 185 in year $t, E_{i, t}$ is the $i$ th early-term ecological factor in year $t, \alpha$ is the productivity parameter, $\beta$ 
186 is the density-dependent parameter, $\gamma_{i}$ is the effect parameter for the $i$ th factor, and $\varepsilon$ is a

187 random error following a normal distribution with mean of 0 and standard deviation of $\sigma$. First, 188 just one early-term factor was included in the Ricker-J model at a time (Table 2), and their 189 relative importance was inferred from the Akaike weights of their corresponding models 190 (Johnson and Omland 2004),

191

$$
\Delta_{i}=A I C_{i}-A I C_{\min }
$$

$$
W_{i}=\frac{e^{-1 / 2 \Delta_{i}}}{\sum_{j=i}^{R} e^{-1 / 2 \Delta_{j}}}
$$

194 where, $A I C_{i}$ is the AIC of the $i$ th model, $A I C_{\text {min }}$ is the AIC of the model with the lowest AIC, $195 W_{i}$ is the Akaike weight of the $i$ th model, $R$ is the number of models. An early-term factor was 196 considered to be candidate if its corresponding Ricker-J model had greater Akaike weight than 197 the basic Ricker-J model without any ecological factors (Table 2). Second, different 198 combinations of the candidate early-term ecological factors were incorporated into the Ricker$199 \mathrm{~J}$ model. The Akaike Information Criteria corrected for small samples (AICc) was used to 200 select the best model representing early-term effects (Burnham and Anderson 2002).

$$
A I C c=A I C+\frac{2 k(k+1)}{N-k-1}
$$


204 where, $N$ is the sample size, and $k$ is the number of parameters in the model. All data were 205 fitted to generalized linear models using version 2.15.0 R software (R Development Core 206 Team 2012). The early-term factors in the best model were considered as the important factors 207 representing early-term effects.

208 Relative importance of middle-term ecological factors on year-class strength

209 The same approach was used to compare the relative importance of middle-term 210 ecological factors, and the candidate factors were selected based on the Akaike weights of 211 their corresponding models (Table 3). Different combinations of the candidate middle-term 212 ecological factors were incorporated into the Ricker-J model to infer the important factors 213 representing middle-term effects (Table 4).

214 Relative effects of SSB, early-term and middle-term factors on age-2 recruitment dynamics

215 Finally, to infer the relative importance of early-term factors on age-2 recruitment

216 dynamics, the important early-term factors were incorporated into a variant of Ricker model, 217 with age-2 recruitment as the response variable,

$$
R_{t+2}=\alpha S_{t} e^{-\beta S_{t}+\sum\left(\gamma_{i} E_{i, t}\right)+\varepsilon}(\text { Ricker-R) }
$$

221 where, $R_{t}$ is the age-2 yellow perch recruitment in year $t, S_{t}$ is the spawning stock biomass in

222 year $t, \sum\left(\gamma_{i} E_{i, t}\right)$ is the linear combination of the important early-term factors in year $t, \alpha$ is the 223 productivity parameter, $\beta$ is the density-dependent parameter, $\gamma$ is the effect parameter for the $224 i$ th factor, and $\varepsilon$ is a random error following a normal distribution with standard deviation of $\sigma$. 225 The same approach was used to incorporate the important middle-term factors to the Ricker-R 
226

227

228

229

model. Then, the Akaike weights of those two models, and the basic Ricker-R model (with no ecological factors), were calculated to rank the relative importance of SSB, early-term, and middle-term ecological factors on age-2 recruitment dynamics (Table 5).

\section{Results}

Variation in yellow perch recruitment was mainly influenced by early- and/or middleterm factors, rather than by SSB or late-term factors. The temporal variability for age-0 $(\mathrm{CV}=1.34)$ and age-1 juvenile densities $(\mathrm{CV}=1.18)$, and age-2 recruitment $(\mathrm{CV}=0.86)$ were much greater than for SSB $(\mathrm{CV}=0.26)$ (Fig. 3), consistent with the idea that, within the range of the available data, variation in factors during early life-history stages largely generates recruitment variation, in addition to that which may be caused by variation in SSB. Among the three step-wise correlations, the SSB was not significantly correlated with age-0 juvenile density, though there were significant correlations between age- 0 juvenile density in year $t$ and age- 1 juvenile density in year $t+1$, as well as between age- 1 juvenile density in year $t+1$ and age-2 recruitment in year $t+2$ (Fig. 4).

Wind speed in May positively affected yellow perch year-class strength and was ranked the most important among the early-term factors (Table 2), from which we inferred that wind speed more likely affected yellow perch year-class strength than the other early-term factors, i.e., dissolved oxygen, bottom water temperature and zooplankton density, for which we had data. As the only candidate early-term factor, it was the only early-term factor selected to represent early-term effects in contrasts among the effects of SSB, early- and middle-term factors on age-2 recruitment dynamics (Table 5).

Among middle-term factors, warming rate negatively, and wind speed positively, related to yellow perch year-class strength (Table 3). Models incorporating warming rate, 
249

250

251

252

253

254

255

256

257

258

259

260

261

262

wind speed, or yearling walleye density had greater Akaike weights than the basic Ricker model, while models incorporating dissolved oxygen, bottom water temperature, and zooplankton and alewife density were weighted much less. Among different combinations of the three candidate middle-term ecological factors, warming rate and wind speed more likely affected yellow perch year-class strength than other middle-term factors, i.e., bottom water temperature, dissolved oxygen, zooplankton, yearling walleye and alewife densities (Table 4); warming rate and wind speed thus represented middle-term factors in contrasts among the effects of SSB, early-term and middle-term effects on age-2 recruitment (Table 5).

Overall, variation of age-2 recruitment was more strongly affected by middle-term factors than by early-term factors or SSB (Fig. 5). The model representing middle-term effects had greater Akaike weight and $\mathrm{R}^{2}$ than the models representing effects of SSB and early-term factors, and was about 2-fold more likely than the basic Ricker model (Table 5).

\section{Discussion}

\section{Stock-recruitment hypothesis}

A strong effect of SSB on recruitment dynamics is assumed for most stock-recruitment models adopted for fisheries management, including the classic Ricker and Beverton-Holt models (Ricker 1954; Beverton and Holt 1957). Despite that, often, any strong relationships between SSB and recruitment are undetected (Koslow 1992), the importance of stockrecruitment relationship for linking consecutive outputs from stock assessment (e.g., statistical catch-at-age models), and to a need to provide management reference points, preserve its popularity among fisheries managers (Subbey et al. 2014). An effect of SSB on recruitment may be detected if there is a sufficiently wide range of variation in SSB (Myers and Barrowman 1996), and we expect recruitment would be reduced under extremely low 
272 spawning stock biomass (at the extreme case, there will be no recruitment if SSB is zero).

273 However, the actual variation of SSB in a fishery may not be great enough to pose a strong

274 effect on recruitment, and the effects of other ecological factors may drive recruitment

275 dynamics in a way that is independent with variation in SSB (Vert-pre et al. 2013). We did not

276 find strong effects of SSB on yellow perch recruitment in the western basin of Lake Erie

277 (Table 5), nor a clear stock-recruitment relationship (Fig. 6), consistent with previous work

278 which did not detect any strong effects of SSB and spawning stock age structure on yellow

279 perch recruitment across three basins of Lake Erie (Zhang et al. 2015). Collectively, this

280 evidence is consistent with the idea that yellow perch recruitment was mainly driven by other

281 ecological factors acting on early life-history stages.

282 Late-term effects and establishment of recruitment strength

In contrast to the stock-recruitment hypothesis, other recruitment hypotheses focussed

284 on the ecological factors acting on early life-history stages (Houde 2008). The natural

mortality rate typically decreases over early life-history stages, and variation in mortality

286 during the fragile and vulnerable egg and larval stages may strongly affect subsequent

287 recruitment (Koslow 1992). Recruitment strength (i.e., the relative size of recruitment to adult

288 population) is generally determined at larval stages for marine fish species and at the juvenile

289 stage for freshwater species (Bradford 1992; Houde 1994). As such, juvenile index surveys

290 may be used to make short-term recruitment predictions for freshwater species, an approach

291 that is currently applied in assessments of yellow perch and walleye fisheries in Lake Erie

292 (Belore et al. 2014; Wills et al. 2014). We did not find strong late-term effects on yellow perch

293 recruitment in the western basin of Lake Erie, suggesting that the recruitment strength was

294 established within the first four months after spawning (i.e., during early- and/or middle-term). 
295 Our results are consistent with Janetski et al. (2013), who showed that yellow perch

296 recruitment strength in Lake Muskegon was established within the first few months after

297 spawning. However, yellow perch recruitment in Lake Huron was not established until age-1

298 (Ivan et al. 2011), and strong correlations between age-0 and age-1 yellow perch were not

299 observed in Lake St. Clair (Henderson and Nepszy 1988). Therefore, the relative importance

300 of late-term effects and the determination time of recruitment strength should be evaluated

301 from a context-dependent perspective.

302 Early-term effects

Fish mortality from starvation during transition from endogenous to exogenous feeding

304 (first few days of swim-up larval stage) was found to be critical to recruitment strength for

305 Atlantic herring in Norway, leading to the "critical period" hypothesis (Hjort 1914). Similarly,

306 the "match-mismatch" hypothesis considered that prey availability around spawning time was

307 key for successful recruitment (Cushing 1975). We did not detect strong effects of early-term

308 factors on recruitment of Lake Erie yellow perch. Further, among those early-term factors, the

309 bottom-up effect of zooplankton density was weaker than the physical effects of wind speed,

310 dissolved oxygen and bottom water temperature on yellow perch year-class strength.

311 Therefore, the "critical period" and "match-mismatch" hypotheses, which focus on early-term

312 effects, were not supported.

313 Wind speed might positively or negatively affect egg survival. On the one hand, low

314 oxygen concentration is an important cause of egg mortality (Köster et al. 2003), and strong

315 winds may facilitate oxygenation of the benthic eggs in the nearshore area. On the other hand,

316 strong water currents generated by strong wind may cause egg destruction, and/or

317 displacement from spawning sites to less favorable areas (Clady 1976). In our study, the 
318 positive effects of wind speed and dissolved oxygen suggested that egg mortality controlled by 319 oxygen availability might affect yellow perch survival. However, the effect of dissolved 320 oxygen concentration on yellow perch egg and yolk-sac larvae survival is not as well studied, 321 and may be a fruitful area for future research.

322

\section{Middle-term effects}

Contrasting with hypotheses about factors causing early-term mortality, is another school of thought about the importance of size related mortality during the larval and earlyjuvenile stages (middle-term) (Anderson 1988; Bailey and Houde 1989; Pepin and Myers 1991). Growth during early life-history stages may negatively affect cumulative mortality, because fast growing individuals usually have greater energy reserves which reduce starvation risk (Anderson 1988), larger body size and ability to better escape predation (Bailey and Houde 1989), and shorter duration of the fragile larval period (Pepin and Myers 1991). For Lake Erie yellow perch, variation in recruitment was mainly affected by middle-term factors. In particular, water warming rate in spring, which negatively affected yellow perch year-class strength, was the most important ecological factor.

Spring warming rate may affect yellow perch growth through three mechanisms. First, high rates of warming may disrupt spawning phenology, affecting prey availability during the growing season. Yellow perch spawning time was affected by both water temperature and photoperiod (Starzynski and Lauer 2015). In short winters when warming rate was high, the optimal spawning temperature was reached early in the year, but the photoperiod condition was not appropriate, leading to delayed spawning at sub-optimal water temperature (Farmer et al. 2015). On the other hand, the zooplankton cycle, better synchronized to changes in water temperature, may lead to a temporal mismatch between fish larvae and peak zooplankton 
341 abundance (Cushing 1975). Second, warming rate may affect reproductive traits, further 342 affecting growth rate during the larval stage. Egg size and size-at-hatch were smaller for 343 yellow perch spawning in years with high warming rates and short winters in Lake Erie

344 (Farmer et al. 2015), which may decrease larval growth rate and increase mortality (Berkeley 345 et al. 2004a). Third, warming rate may affect larval growth via changes in hatching date.

346 Following long winters with slow warming rates, spawning and hatch dates were usually late 347 (Starzynski and Lauer 2015), and later-hatching yellow perch had greater growth rates and 348 survival (Weber et al. 2011).

Regardless of the mechanisms affecting larval growth, the ultimate cause of mortality was either a bottom-up effect, via starvation, or a top-down effect, via predation. Both bottom-

351 up and top-down effects on yellow perch recruitment have been detected in the Laurentian

352 Great Lakes region (Janssen et al. 2014; Pritt et al. 2014). Zooplankton abundance was an 353 important factor affecting yellow perch survival in Lake Michigan (Dettmers et al. 2003), and 354 both walleye and alewife exerted strong top-down effects on yellow perch recruitment 355 (Hartman and Margraf 1993; Mason and Brandt 1996; Redman et al. 2011). In our study, the 356 effect of yearling walleye on yellow perch year-class strength was much greater than the 357 effects of alewife or zooplankton. Other studies in the western basin of Lake Erie also found 358 greater yellow perch larval survival in the Maumee river plume, likely due to reduced 359 predation risk (Reichert et al. 2010; Carreon-Martinez et al. 2014). Therefore, the interaction 360 between growth rate and predation during middle-term, which was linked with various biotic 361 and abiotic factors, may strongly affect yellow perch recruitment in the western basin of Lake 362 Erie. 

continues to substantially challenge fisheries science and management (Essington et al. 2015).

366 For many fish species, population dynamics is strongly affected by recruitment variability

367 (Caley et al. 1996). A major effect of harvest on a population is the removal of SSB. Therefore, 368 evaluating the relative effect of SSB on recruitment dynamics provides insight with respect to 369 the effect of harvest on population dynamics. A strong effect of SSB on recruitment means 370 recruitment strength is sensitive to variation in SSB, suggesting, in turn, strong effects of 371 harvest on population dynamics. On the other hand, if recruitment is largely insensitive to 372 variation in SSB, it is implied that effect of harvest on recruitment dynamics through its effect 373 on SSB is also weak. Nevertheless, fisheries managers need to remain cognizant of other 374 potential effects of harvest, such as changes to population age structure and/or habitat (Auster 375 and Langton 1999; Berkeley et al. 2004b).

Variation in SSB appears to have had relatively smaller effects than environmental

377 variation on yellow perch recruitment in the western basin of Lake Erie; neither does there 378 appear to be positive effects of population age structure on recruitment (Zhang et al. 2015).

379 Together, these results suggest that coupled physical and biological processes during middle380 term may be most important factors affecting recruitment by yellow perch. Our results 381 underscore the importance of physical-biological modelling to study freshwater fish 382 recruitment in large lakes is recognized (Janssen et al. 2014; Ludsin et al. 2014).

\section{Recruitment prediction} decades due to its importance to fisheries management, and the challenge it represents for 
387 time series data raises the issue of whether complex models might be overfitted to sparse data, 388 leading to poor predictive power (Ginzburg and Jensen 2004). Here, we were challenged by 389 the need to constrain our data to 15 years, i.e., the shortest of the time series available among 390 the environmental variables we investigated. To reduce the risk of overfitting, we used the 391 simple generalized linear regression model, restricted the majority of our models to two or 392 three parameters, and used AICc for model comparisons among more complex models.

393 Despite this, our "best" model may still have a relatively low predictive power.

In any case, instead of building a single "best" predictive model, we aimed to compare 395 the relative importance of ecological factors acting at different early life-history stages to 396 influence recruitment dynamics, which may help to determine future research priorities.

397 Correlative recruitment models have been criticized for poor predictive power (Walters and 398 Collie 1988; Myers 1998), and more mechanistic models, e.g., individual-based model and 399 spatial-explicit model, have gained popularity in fisheries research (Werner et al. 2001; 400 Hedger et al. 2013; Persson et al. 2014). A conflict exists between the great data demand of 401 these mechanistic models and the limited resources of research institutions and management 402 agencies to collect those data. We systematically sifted among multiple alternative hypotheses about mechanisms driving recruitment, and found strong effects of physical-biological 404 processes during the middle-term (June to August). This suggests that there is merit in 405 collecting more middle-term ecological data to support development of spatially-explicit, 406 individual-based models, to better understand and predict yellow perch recruitment in Lake 407 Erie (Ludsin et al. 2014). juvenile stages primarily drove recruitment by Lake Erie yellow perch; effects of SSB, early- 
term and late-term factors were less important. Physical environmental factors, such as spring warming rate and wind speed, had stronger effects than biological factors, such as walleye and zooplankton densities, on recruitment, confirming the importance of coupling physical and biological processes in understanding fish recruitment mechanisms in large lakes. The failure to detect a strong effect of SSB on recruitment suggests that the relative effect of harvest on yellow perch population dynamics may be weak during our study period. Nevertheless, the relative importance of different factors may change over time, due to changing interactions among ecological factors driven by ecosystem regime shifts (DeYoung et al. 2004; Brander 2005; Hare 2014).

\section{Acknowledgements}

This research was funded by a Natural Sciences and Engineering Research Council of Canada Strategic Networks grant to Canadian Fisheries Research Network and a grant-in-aid of research from the Ontario Commercial Fisheries' Association. We thank Robert McLaughlin (University of Guelph), Dan Gillis (University of Guelph), Jake Rice (Fisheries and Oceans Canada), Beren Robinson (University of Guelph), and two anonymous reviewers for comments that improved earlier drafts of this manuscript. We thank David Gíslason (University of Guelph) for providing data on percentage maturation at age of Lake Erie yellow perch. We thank the Lake Erie Management Unit (Ontario Ministry of Natural Resources and Forestry) for providing biotic and abiotic data used for this study. Data for this research was provided to the authors under written agreement with the Lake Erie Committee.

\section{References}

Anderson, J.T. 1988. A review of size dependent survival during pre-recruit stages of fishes in relation to recruitment. J. Northwest Atl. Fish. Sci. 8: 55-66. doi: 10.1.1.467.4638.

Auster, P., and Langton, R. 1999. The effects of fishing on fish habitat. Am. Fish. Soc. Simp. 22: $150-187$. 
435

436

437

438

439

440

441

442

443

444

445

446

447

448

449

450

451

452

453

454

455

456

457

458

459

460

461

462

463

464

465

466

467

468

469

470

471

472

473

Bailey, K.M., Ciannelli, L., Bond, N.A., Belgrano, A., and Stenseth, N.C. 2005. Recruitment of walleye pollock in a physically and biologically complex ecosystem: A new perspective. Prog. Oceanogr. 67(1-2): 24-42. doi: 10.1016/j.pocean.2005.06.001.

Bailey, K.M., and Houde, E.D. 1989. Predation on eggs and larvae of marine fishes and the recruitment problem. Adv. Mar. Biol. 25: 1-83. doi: 10.1016/S0065-2881(08)60187-X.

Begg, G.A., and Marteinsdottir, G. 2002. Environmental and stock effects on spawning origins and recruitment of cod Gadus morhua. Mar. Ecol. Prog. Ser. 229: 263-277. doi: $10.3354 /$ meps 229263 .

Belore, M., Cook, A., Hartman, T., Hosack, M., Kayle, K., Knight, C., Markham, J., Murray, C., Thomas, M., and Witzel, L. 2014. Report of the Lake Erie Yellow Perch Task Group.

Berkeley, S.A., Chapman, C., and Sogard, S.M. 2004a. Maternal age as a determinant of larval growth and survival in a marine fish, Sebastes melanops. Ecology 85(5): 1258-1264. doi: 10.1890/03-0706.

Berkeley, S.A., Hixon, M.A., Larson, R.J., and Love, M.S. 2004b. Fisheries sustainability via protection of age structure and spatial distribution of fish populations. Fisheries 29(8): 23-32. doi: 10.1577/1548-8446(2004)29.

Beverton, R.J.H., and Holt, S.J. 1957. Fisheries investigation series. In On the dynamics of exploited fish populations. Ministry of Agriculture, Fisheres and Food, London. p. 19.

Bradford, M.J. 1992. Precision of recruitment predictions from early life stages of marine fishes. Fish. Bull. 90: 439-453. Available from http://fishbull.noaa.gov/903/bradford.pdf.

Brander, K.M. 2005. Cod recruitment is strongly affected by climate when stock biomass is low. ICES J. Mar. Sci. 62(3): 339-343. doi: 10.1016/j.icesjms.2004.07.029.

Burnham, K.P., and Anderson, D.R. 2002. Model selection and multimodel inference: A practical information-theoretic approach. Springer-Verlag, New York.

Caley, M.J., Carr, M.H., Hixon, M.A., Hughes, T.P., Jones, G.P., and Menge, B.A. 1996. Recruitment and the local dynamics of open marine populations. Annu. Rev. Ecol. Syst. 27: 477-500. Available from http://www.jstor.org/stable/2097243.

Carreon-Martinez, L.B., Wellband, K.W., Johnson, T.B., Ludsin, S.A., and Heath, D.D. 2014. Novel molecular approach demonstrates that turbid river plumes reduce predation mortality on larval fish. Mol. Ecol. 23: 5366-5377. doi: 10.1111/mec.12927.

Clady, M.D. 1976. Influence of temperature and wind on the survival of early stages of yellow perch, Perca flavescens. J. Fish. Board Canada 33(9): 1887-1893. doi: 10.1139/f76-241.

Cury, P., and Roy, C. 1989. Optimal environmental window and pelagic fish recruitment success in upwelling areas. Can. J. Fish. Aquat. Sci. 46(4): 670-680. doi: 10.1139/f89086.

Cushing, D.H. 1975. Marine Ecology and Fisheries. Cambridge University Press, New York.

Dettmers, J.M., Raffenberg, M.J., and Weis, A.K. 2003. Exploring zooplankton changes in Southern Lake Michigan: implications for yellow perch recruitment. J. Great Lakes Res. 29(2): 355-364. doi: 10.1016/S0380-1330(03)70439-0. 
474

475

476

477

478

479

480

481

482

483

484

485

486

487

488

489

490

491

492

493

494

495

496

497

498

499

500

501

502

503

504

505

506

507

508

509

510

511

512

513

DeYoung, B., Harris, R., Alheit, J., Beaugrand, G., Mantua, N., and Shannon, L. 2004. Detecting regime shifts in the ocean: Data considerations. Prog. Oceanogr. 60(2-4): 143164. doi: 10.1016/j.pocean.2004.02.017.

Essington, T.E., Moriarty, P.E., Froehlich, H.E., Hodgson, E.E., Koehn, L.E., Oken, K.L., Siple, M.C., and Stawitz, C.C. 2015. Fishing amplifies forage fish population collapses. Proc. Natl. Acad. Sci. 112(21): 6648-6652. doi: 10.1073/pnas.1422020112.

Farmer, T.M., Marschall, E.A., Dabrowski, K., and Ludsin, S.A. 2015. Short winters threaten temperate fish populations. Nat. Commun. 6: 7724. Nature Publishing Group. doi: $10.1038 /$ ncomms 8724 .

Ginzburg, L.R., and Jensen, C.X.J. 2004. Rules of thumb for judging ecological theories. Trends Ecol. Evol. 19(3): 121-126. doi: 10.1016/j.tree.2003.11.004.

Griffiths, R.W., Schloesser, D.W., Leach, J.H., and Kovalak, W.P. 1991. Distribution and dispersal of the zebra mussel (Dreissena polymorpha) in the Great Lakes region. Can. J. Fish Aquat. Sci. 48: 1381-1388. Available from http://www.nrcresearchpress.com/doi/abs/10.1139/f91-165.

Hare, J.A. 2014. The future of fisheries oceanography lies in the persuit of multiple hypotheses. ICES J. Mar. Sci. 71(8): 2343-2356. doi: 10.1039/icesjms/fsu018.

Hartman, K.J., and Margraf, F.J. 1993. Evidence of predatory control of yellow perch (Perca flavescens) recruitment in Lake Erie, U.S.A. J. Fish Biol. 43: 109-119. doi: 10.1111/j.1095-8649.1993.tb00414.x.

Hedger, R.D., Sundt-Hansen, L.E., Forseth, T., Diserud, O.H., Ugedal, O., and Finstad, A.G. 2013. Modelling the complete life-cycle of Atlantic salmon (Salmo salar L.) using a spatially explicit individual-based approach. Ecol. Modell. 248: 119-129. Elsevier B.V. doi: 10.1016/j.ecolmodel.2012.10.003.

Henderson, B.A. 1985. Factors affecting growth and recruitment of yellow perch, Perca flavescens Mitchill, in South Bay, Lake Huron. J. Fish Biol. 26(4): 449-458. doi: 10.1111/j.1095-8649.1985.tb04284.x.

Henderson, B.A., and Nepszy, S.J. 1988. Recruitment of yellow perch (Perca flavescens) affected by stock size and water temperature in Lakes Erie and St. Clair, 1965-85. J. Great Lakes Res. 14(2): 205-215. doi: 10.1016/S0380-1330(88)71549-X.

Henderson, B.A., Trivedi, T., and Collins, N. 2000. Annual cycle of energy allocation to growth and reproduction of yellow perch. J. Fish Biol. 57(1): 122-133. doi: 10.1006/jfbi.2000.1293.

Hjort, J. 1914. Fluctuations in the great fisheries of northern Europe: viewed in the light of biological research. In Rapports Et Procés-verbaux Des Réunions volume 20. pp. 1-228.

Houde, E.D. 1994. Differences between marine and freshwater fish larvae: implications for recruitment. ICES J. Mar. Sci. 51(1): 91-97. doi: 10.1006/jmsc.1994.1008.

Houde, E.D. 2008. Emerging from Hjort's shadow. J. Northwest Atl. Fish. Sci. 41: 53-70. doi: 10.2960/J.v41.m634.

Ivan, L.N., Höök, T.O., Thomas, M. V., and Fielder, D.G. 2011. Long-term and interannual 
dynamics of walleye and yellow perch in Saginaw Bay, Lake Huron. Trans. Am. Fish. Soc. 140(4): 1078-1092. doi: 10.1080/00028487.2011.603976.

Janetski, D.J., Ruetz, C.R., Bhagat, Y., and Clapp, D.F. 2013. Recruitment dynamics of age-0 yellow perch in a drowned river mouth lake: assessing synchrony with nearshore Lake Michigan. Trans. Am. Fish. Soc. 142(2): 505-514. doi: 10.1080/00028487.2012.756432.

Janssen, J., Marsden, J.E., Hrabik, T.R., and Stockwell, J.D. 2014. Are the Laurentian Great Lakes great enough for Hjort? ICES J. Mar. Sci. doi: 10.1093/icesjms/fst220.

Johnson, J.B., and Omland, K.S. 2004. Model selection in ecology and evolution. Trends Ecol. Evol. 19(2): 101-8. doi: 10.1016/j.tree.2003.10.013.

Koslow, A.J. 1992. Fecundity and the stock-recruitment relationship. Can. J. Fish. Aquat. Sci. 49(2): 210-217. doi: 10.1139/f92-025.

Köster, F.W., Hinrichsen, H., Schnack, D., John, M.A.S.T., Mackenzie, B.R., Tomkiewicz, J., Möllmann, C., Kraus, G., Plikshs, M., Makarchouk, A., and Aro, E. 2003. Recruitment of Baltic cod and sprat stocks: identification of critical life stages and incorporation of environmental variability into stock-recruitment relationships. Sci. Mar. 67: 129-154. doi: 10.3989/scimar.2003.67s1129.

Lasker, R. 1975. Field criteria for survival of anchovy larvae: the relation between inshore chlorophyll maximum layers and successful first feeding. Fish. Bull. 73(3): 453-462. Available from http://fishbull.noaa.gov/73-3/lasker.pdf.

Lees, K., Pitois, S., Scott, C., Frid, C., and MacKinson, S. 2006. Characterizing regime shifts in the marine environment. Fish Fish. 7: 104-127. doi: 10.1111/j.14672979.2006.00215.x.

Ludsin, S.A., Devanna, K.M., and Smith, R.E.H. 2014. Physical-biological coupling and the challenge of understanding fish recruitment in freshwater lakes. Can. J. Fish. Aquat. Sci. 71: 775-794. doi: dx.doi.org/10.1139/cjfas-2013-0512.

Mason, D.M., and Brandt, S.B. 1996. Effect of alewife predation on survival of larval yellow perch in an embayment of Lake Ontario. Can. J. Fish. Aquat. Sci. 53: 1609-1617. doi: 10.1139/f96-076.

Mertz, G., and Myers, R.A. 1995. Estimating the predictability of recruitment. Fish. Bull. 93: 657-665.

Myers, R.A. 1998. When do environment-recruitment correlations work? Rev. Fish Biol. Fish. 8: 285-305. doi: 10.1023/A:1008828730759.

Myers, R.A., and Barrowman, N.J. 1996. Is fish recruitment related to spawner abundance? Fish. Bull. 94(4): 707-724. Available from http://fishbull.noaa.gov/944/myers.pdf.

Nash, R.D.M. 1998. Exploring the population dynamics of Irish Sea plaice, Pleuronectes platessa L., through the use of Paulik diagrams. J. Sea Res. 40(1-2): 1-18. doi: 10.1016/S1385-1101(98)00012-4.

Pepin, P. 2015. Reconsidering the impossible- linking environmental drivers to growth, mortality, and recruitment of fish. Can. J. Fish Aquat. Sci. 72. doi: 10.1139/cjfas-20150091. 
554

555

556

557

558

559

560

561

562

563

564

565

566

567

568

569

570

571

572

573

574

575

576

577

578

579

580

581

582

583

584

585

586

587

588

589

590

591

592

593

Pepin, P., and Myers, R.A. 1991. Significance of egg and larval size to recruitment variability of temperate marine fish. Can. J. Fish. Aquat. Sci. 48: 1820-1828. doi: 10.1139/f91-215.

Persson, L., Leeuwen, A. Van, and De Roos, A.M. 2014. The ecological foundation for ecosystem-based management of fisheries: mechanistic linkages between the individual, population- and community-level dynamics. ICES J. Mar. Sci. 71(8): 2268-2280. doi: 10.1093/icesjms/fst231.

Pritt, J.J., Roseman, E.F., and O’Brien, T.P. 2014. Mechanisms driving recruitment variability in fish: comparisons between the Laurentian Great Lakes and marine systems. ICES J. Mar. Sci. 71(8): 2252-2267. doi: 10.1093/icesjms/fsu080.

R Development Core Team. 2012. R: A language and environment for statistical computing. R Foundation for Statistical Computing, Vienna, Austria. Available from http://www.rproject.org/.

Redman, R.A., Czesny, S.J., Dettmers, J.M., Weber, M.J., and Makauskas, D. 2011. Old tales in recent context: current perspective on yellow perch recruitment in Lake Michigan. Trans. Am. Fish. Soc. 140(5): 1277-1289. doi: 10.1080/00028487.2011.620480.

Reichert, J.M., Fryer, B.J., Pangle, K.L., Johnson, T.B., Tyson, J.T., Drelich, A.B., and Ludsin, S.A. 2010. River-plume use during the pelagic larval stage benefits recruitment of a lentic fish. Can. J. Fish. Aquat. Sci. 67: 987-1004. doi: 10.1139/F10-036.

Ricker, W.E. 1954. Stock and recruitment. J. Fish. Res. Board Canada 11(5): 559-623. doi: 10.1139/f54-039.

Rose, K.A., Rutherford, E.S., McDermot, D.S., Forney, J.L., and Mills, E.L. 1999. Individualbased model of yellow perch and walleye populations in Oneida Lake. Ecol. Monogr. 69(2): 127-154. doi: 10.1890/0012-9615(1999)069[0127:IBMOYP]2.0.CO;2.

Shroyer, S., and McComish, T. 2000. Relationship between alewife abundance and yellow perch recruitment in southern Lake Michigan. North Am. J. Fish. Manag. 20: 220-225. doi: $10.1577 / 1548-8675(2000) 020<0220$.

Starzynski, D., and Lauer, T.E. 2015. How temperature affects timing and duration of yellow perch spawning in the Indiana waters of Lake Michigan. J. Freshw. Ecol. 30: 445-453. doi: $10.1080 / 02705060.2014 .988761$.

Subbey, S., Devine, J.A., Schaarschmidt, U., and Nash, R.D.M. 2014. Modelling and forecasting stock-recruitment: current and future perspectives. ICES J. Mar. Sci.: 12051217. doi: 10.1093/icesjms/fst048.

Sztramko, L., and Teleki, G.C. 1977. Annual variations in the fecundity of yellow perch from Long Point Bay, Lake Erie. Trans. Am. Fish. Soc. 106(6): 578-582. doi: 10.1577/15488659(1977)106<578:AVITFO>2.0.CO;2.

Thomas, M., Biesinger, Z., Deller, J., Hosack, M., Kocovsky, P., MacDougall, T., Markham, J., Pérez-fuentetaja, A., Weimer, E., and Witzel, L. 2014. Report of the Lake Erie Forage Task Group.

Tyson, J.T., and Knight, R.L. 2001. Response of yellow perch to changes in the benthic invertebrate community of western Lake Erie. Trans. Am. Fish. Soc. 130: 766-782. doi: 
600

601

602

603

604

605

606

607

608

609

610

611

612

613

614

615

616

617

618

619

620
10.1577/1548-8659(2001)130.

Vert-pre, K.A., Amoroso, R.O., Jensen, O.P., and Hilborn, R. 2013. Frequency and intensity of productivity regime shifts in marine fish stocks. Proc. Natl. Acad. Sci. U. S. A. 110(5): 1779-84. doi: 10.1073/pnas.1214879110.

Walters, C.J., and Collie, J.S. 1988. Is research on environmental factors useful to fisheries management? Can. J. Fish. Aquat. Sci. 45(1): 1848-1854. doi: 10.1139/f88-217.

Weber, M.J., Dettmers, J.M., and Wahl, D.H. 2011. Growth and survival of age-0 yellow perch across habitats in southwestern Lake Michigan: early life history in a large freshwater environment. Trans. Am. Fish. Soc. 140(5): 1172-1185. doi: 10.1080/00028487.2011.608605.

Werner, F.E., Quinlan, J.A., Lough, R.G., and Lynch, D.R. 2001. Spatially-explicit individual based modeling of marine populations: A review of the advances in the 1990's. Sarsia 86(6): 411-421.

Wills, T., Markham, J., Kayle, K., Gorman, A.M., Vandergoot, C., Belore, M., Cook, A., Drouin, R., Macdougall, T., Zhao, Y., Murray, C., and Hosack, M. 2014. Report for 2013 by the Lake Erie Walleye Task Group. Windsor, Ontario.

Wu, L., and Culver, D.A. 1992. Ontogenetic diet shift in Lake Erie age-0 yellow perch (Perca flavescens): a size-related response to zooplankton density. Can. J. Fish. Aquat. Sci. 49: 1932-1937. doi: 10.1139/f92-214.

Zhang, F., Reid, K.B., and Nudds, T.D. 2015. Counterintuitive patterns of spawning stock age structure and recruitment in Lake Erie yellow perch (Perca flavescens). Can. J. Fish Aquat. Sci. 72: 1494-1502. doi: 10.1139/cjfas-2014-0489.

Zwolinski, J.P., and Demer, D.A. 2014. Environmental and parental control of Pacific sardine (Sardinops sagax) recruitment. ICES J. Mar. Sci. 71(8): 2198-2207. doi: 10.1093/icesjms/fst173. 
621 Table 1. The min, max, mean and coefficient of variation (CV) of early-term and middle-term

622 factors in the western basin of Lake Erie between 1999 and 2013.

\begin{tabular}{lcccc}
\hline Ecological factor & Min & Max & Mean & CV \\
Early-term & & & & \\
Bottom water temperature & 11.97 & 17.56 & 14.44 & 0.11 \\
Wind speed & 2.50 & 16.67 & 8.69 & 0.54 \\
Dissolved oxygen & 7.99 & 11.07 & 9.88 & 0.11 \\
Zooplankton density & 0.99 & 72.38 & 20.65 & 1.05 \\
Middle-term & & & & \\
Bottom water temperature & 19.62 & 22.39 & 20.94 & 0.043 \\
Wind speed & 0 & 6.70 & 11.46 & 0.28 \\
Dissolved oxygen & 8.08 & 9.73 & 8.88 & 0.055 \\
Zooplankton density & 176.3 & 813.4 & 387 & 0.53 \\
Warming rate & 0.10 & 0.20 & 0.24 & 0.18 \\
Ylewife density & 0.11 & 45.50 & 5.03 & 2.29 \\
\hline & 0 & 291 & 44.76 & 2.23 \\
\hline & & & & \\
\hline
\end{tabular}

623

624 
625 Table 2. Comparison of Ricker-J models incorporating early-term ecological factors through

626 May in the western basin of Lake Erie between 1999 and 2013. * indicates the candidate

627 early-term ecological factors, and the bolded model is the one selected to represent early-term 628 effects.

\begin{tabular}{|c|c|c|c|c|c|c|c|}
\hline Model & $\begin{array}{l}\text { Ecological variables } \\
\text { (effect direction) }\end{array}$ & Parameter & $\mathrm{df}$ & $\mathrm{R}^{2}$ & AIC & $\begin{array}{l}\text { Scaled } \\
\text { AIC }\end{array}$ & $\begin{array}{l}\text { Akaike } \\
\text { weight }\end{array}$ \\
\hline $\begin{array}{l}\text { Ricker- } \\
\text { J(WR) }\end{array}$ & wind speed $*(+)$ & 3 & 12 & 0.16 & 49.58 & 0 & 0.32 \\
\hline Ricker-J & none & 2 & 13 & 0.016 & 49.90 & 0.32 & 0.28 \\
\hline $\begin{array}{l}\text { Ricker- } \\
\mathrm{J}(\mathrm{DO})\end{array}$ & dissolved oxygen $(+)$ & 3 & 12 & 0.080 & 50.88 & 1.30 & 0.13 \\
\hline $\begin{array}{l}\text { Ricker- } \\
\text { J(WT) }\end{array}$ & $\begin{array}{l}\text { bottom water } \\
\text { temperature }(+)\end{array}$ & & 12 & 0.044 & 51.46 & 1.88 & 0.17 \\
\hline $\begin{array}{l}\text { Ricekr- } \\
\mathrm{J}(\mathrm{ZD})\end{array}$ & $\begin{array}{l}\text { zooplankton density } \\
(+)\end{array}$ & 3 & 12 & 0.017 & 51.88 & 2.30 & 0.10 \\
\hline
\end{tabular}

629 
631 Table 3. Comparison of Ricker models incorporating middle-term ecological factors from June

632 through August in the western basin of Lake Erie between 1999 and 2013. * indicates the

633 candidate middle-term ecological factors.

\begin{tabular}{|c|c|c|c|c|c|c|c|}
\hline Model & $\begin{array}{l}\text { Ecological variable } \\
\text { (effect direction) }\end{array}$ & Parameter & $\mathrm{df}$ & $\mathrm{R}^{2}$ & AIC & $\begin{array}{l}\text { Scaled } \\
\text { AIC }\end{array}$ & $\begin{array}{l}\text { Akaike } \\
\text { weight }\end{array}$ \\
\hline $\begin{array}{l}\text { Ricker- } \\
\text { J(WR) }\end{array}$ & warming rate* (-) & 3 & 12 & 0.26 & 47.55 & 0 & 0.33 \\
\hline $\begin{array}{l}\text { Ricker- } \\
\mathrm{J}(\mathrm{WS})\end{array}$ & wind speed* $\left.{ }^{*}+\right)$ & 3 & 12 & 0.23 & 48.31 & 0.76 & 0.22 \\
\hline $\begin{array}{l}\text { Ricker- } \\
\text { J(WL) }\end{array}$ & $\begin{array}{l}\text { yearling walleye } \\
\text { density* (-) }\end{array}$ & 3 & 12 & 0.18 & 49.10 & 1.55 & 0.15 \\
\hline Ricker-J & none & 2 & 13 & 0.016 & 49.90 & 2.35 & 0.10 \\
\hline $\begin{array}{l}\text { Ricker- } \\
\text { J(DO) }\end{array}$ & dissolved oxygen $(+)$ & 3 & 12 & 0.071 & 51.03 & 3.48 & 0.058 \\
\hline Ricker- & zooplankton density & 3 & 12 & 0.050 & 51.37 & 3.82 & 0.049 \\
\hline $\mathrm{J}(\mathrm{ZD})$ & $(+)$ & & & & & & \\
\hline Ricker- & bottom water & 3 & 12 & 0.043 & 51.48 & 3.93 & 0.046 \\
\hline $\mathrm{J}(\mathrm{WT})$ & temperature $(+)$ & & & & & & \\
\hline Ricker- & alewife density (-) & 3 & 12 & 0.028 & 51.71 & 4.16 & 0.041 \\
\hline $\mathrm{J}(\mathrm{AL})$ & & & & & & & \\
\hline
\end{tabular}


635 Table 4. Comparison of Ricker models incorporating combinations of candidate middle-term 636 ecological factors from June through August in the western basin of Lake Erie between 1999 637 and 2013. Bolded model is the one selected to represent middle-term ecological effects.

\begin{tabular}{|c|c|c|c|c|c|}
\hline Model & Ecological variable & Parameter & $\mathrm{df}$ & $\mathrm{R}^{2}$ & $\mathrm{AICc}$ \\
\hline Ricker-J(WR+WS) & warming rate, wind speed & 4 & 11 & 0.56 & 45.8 \\
\hline Ricker- & warming rate, wind speed, yearling & 5 & 10 & 0.62 & 48.17 \\
\hline $\mathrm{J}(\mathrm{WR}+\mathrm{WS}+\mathrm{WL})$ & walleye density & & & & \\
\hline Ricker-J(WR) & warming rate & 3 & 12 & 0.26 & 49.73 \\
\hline Ricker-J(WS) & wind speed & 3 & 12 & 0.23 & 50.49 \\
\hline Ricker-J(WR+WL) & $\begin{array}{l}\text { warming rate, yearling walleye } \\
\text { density }\end{array}$ & 4 & 11 & 0.37 & 51.24 \\
\hline Ricker-J(WS+WL) & $\begin{array}{l}\text { wind speed, yearling walleye } \\
\text { density }\end{array}$ & 4 & 11 & 0.36 & 51.25 \\
\hline Ricker-J(WL) & yearling walleye density & 3 & 12 & 0.18 & 51.28 \\
\hline
\end{tabular}


640 Table 5. Comparison of Ricker models representing effects of SSB, early-term and middle-

641 term ecological factors on yellow perch age-2 recruitment dynamic in the western basin of

$642 \quad$ Lake Erie between 1999 and 2013.

\begin{tabular}{llllll}
\hline Model & Meaning & $\mathrm{R}^{2}$ & AIC & Scaled & Akaike \\
& & & & AIC & weight \\
Ricker- & Middle-term effects & 0.33 & 41.93 & 0 & 0.58 \\
R(WR+WS) & & & & & \\
Ricker-R & Effects of SSB & -0.0019 & 43.17 & 1.24 & 0.31 \\
Ricker-R(WS) & Early-term effects & -0.0018 & 45.17 & 3.24 & 0.11 \\
\hline
\end{tabular}

643 


\section{$644 \quad$ Figures}

645 Fig. 1. Life history of yellow perch in the western basin of Lake Erie, and illustration of 646 operationally-defined "early-term", "middle-term", and "late-term" periods encompassing 647 different yellow perch early life-history stages.

648 Fig. 2. Study location in the western basin of Lake Erie.

649 Fig. 3. Temporal variation of spawning stock biomass (SSB), age-0 juvenile density, age-1 650 juvenile density and age-2 recruitment of yellow perch in the western basin of Lake Erie 651 between 1999 and 2013. Variables are log-transformed.

652 Fig. 4. Pair-wise correlations of SSB, age-0 and age-1 juvenile densities, and recruitment of 653 yellow perch in the western basin of Lake Erie between 1999 and 2013 showing relationships 654 between (A) SSB in year t and age-0 juvenile density in August in year t, (B) age-0 juvenile 655 density in August in year $\mathrm{t}$ and age-1 juvenile density in August in year $\mathrm{t}+1$, and (C) age-1 656 juvenile density in August in year $\mathrm{t}+1$ and age- 2 recruitment in year $\mathrm{t}+2$. All data were $\log$ 657 transformed before analyses.

658 Fig. 5. Model fit of the Ricker-R models representing effects of SSB, early-term and middle659 term factors on yellow perch recruitment in the western basin of Lake Erie between 2001 and 660 2013. The black dots are the estimates of recruitment, the solid line is the recruitment 661 prediction by model representing effects of SSB, the dashed line is the recruitment prediction 662 by model representing early-term effects, and the dotted line is the recruitment prediction by 663 model representing middle-term effects.

664 Fig. 6. Model fit of Ricker model to the observed stock-recruitment dynamic. The black dots 665 are the estimates of SSB and recruitment, and the solid line is the prediction by Ricker model. 666 


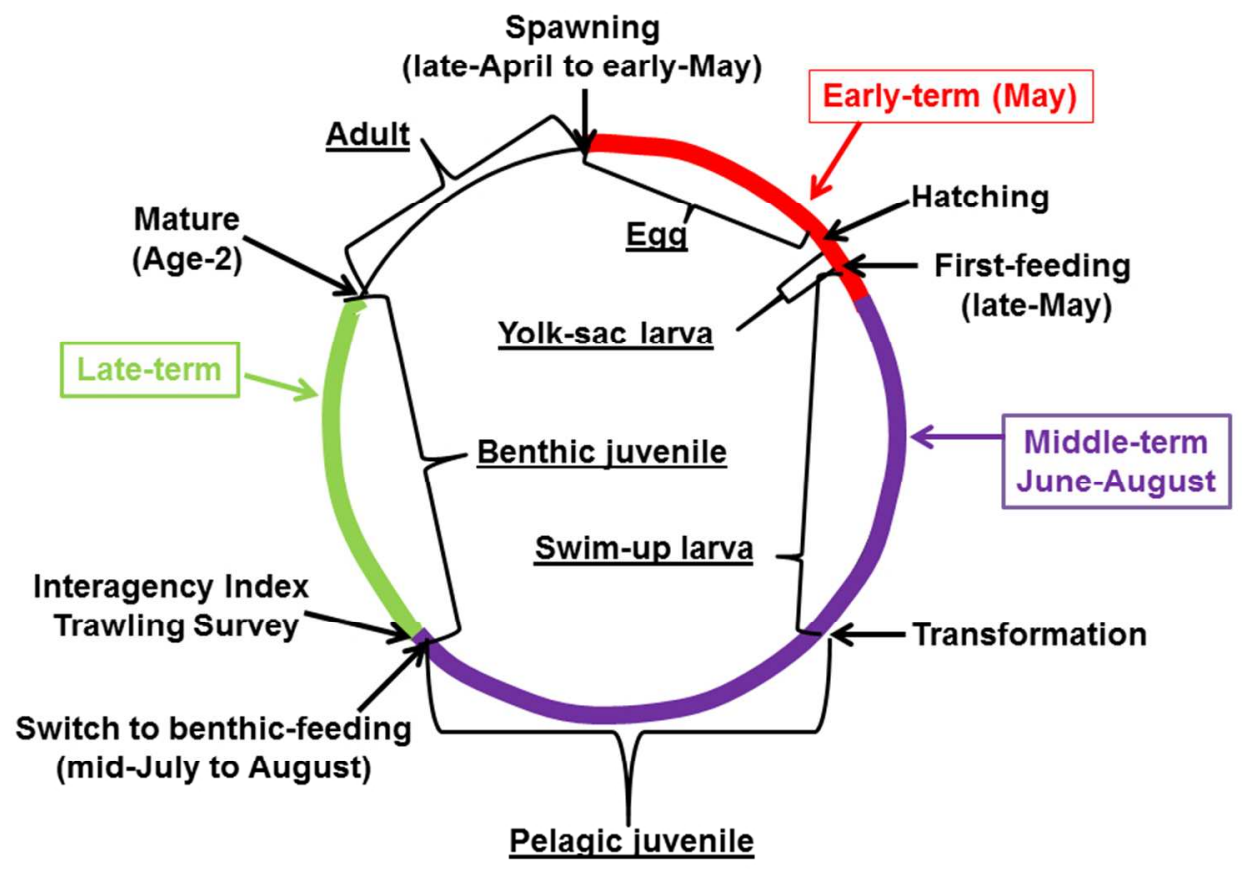

Fig. 1. Life history of yellow perch in the western basin of Lake Erie, and illustration of operationally-defined "early-term", "middle-term", and "late-term" periods encompassing different yellow perch early life-history stages. 


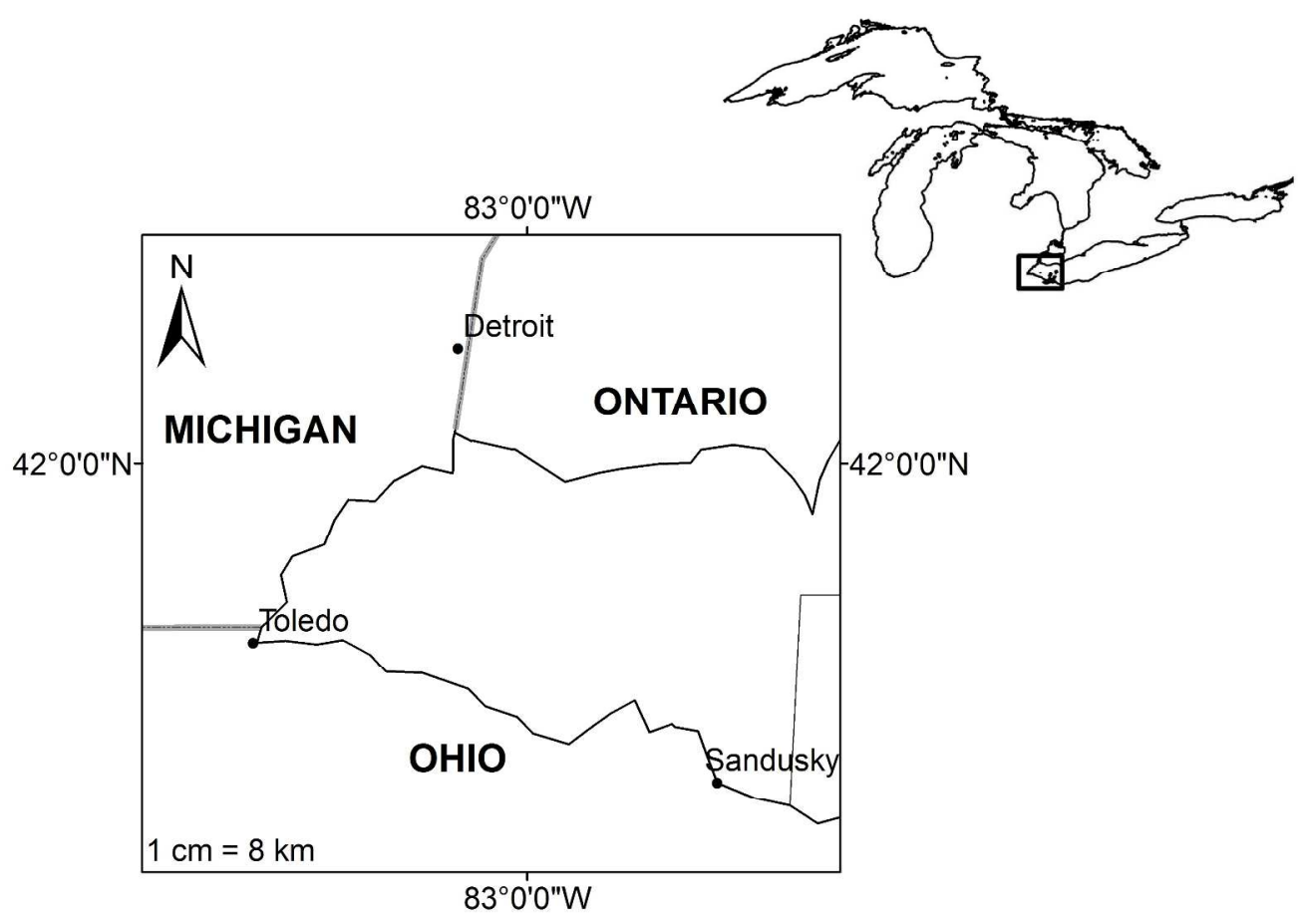

Fig. 2. Study location in the western basin of Lake Erie.

$296 \times 210 \mathrm{~mm}(300 \times 300$ DPI $)$ 

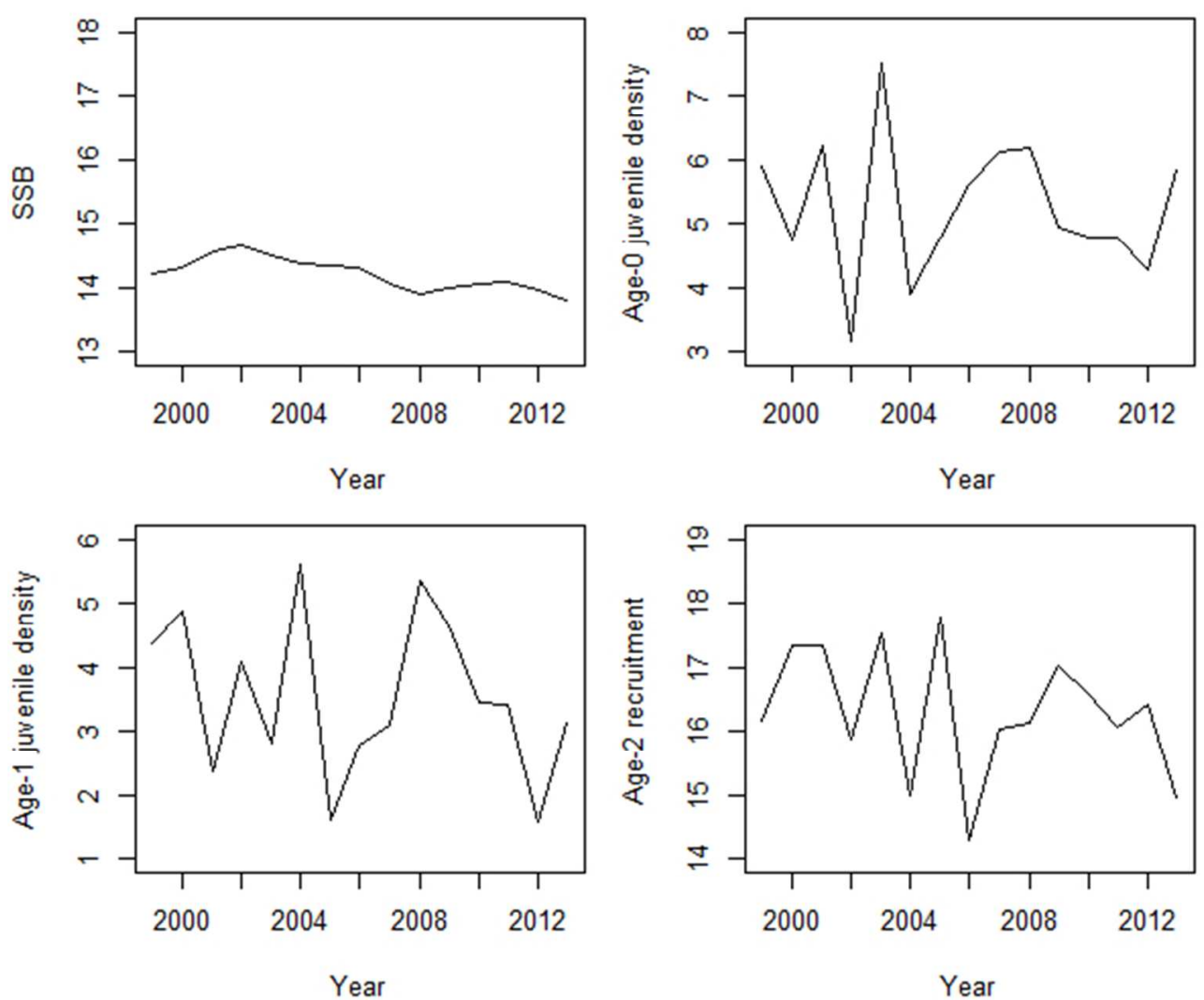

Fig. 3. Temporal variation of spawning stock biomass (SSB), age-0 juvenile density, age-1 juvenile density and age-2 recruitment of yellow perch in the western basin of Lake Erie between 1999 and 2013. Variables are log-transformed.

$211 \times 176 \mathrm{~mm}(72 \times 72 \mathrm{DPI})$ 

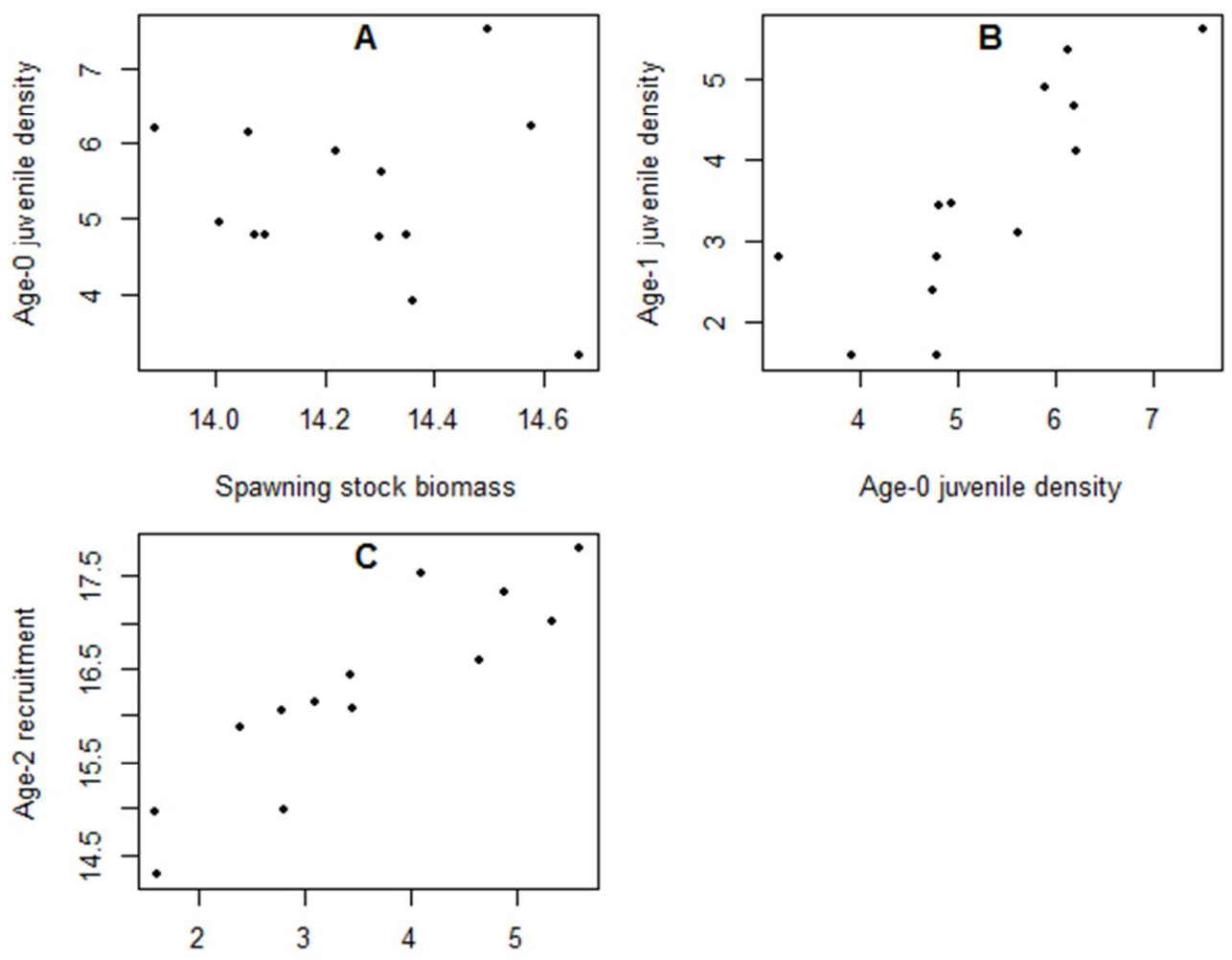

Age-0 juvenile density

Age-1 juvenile density

Fig. 4. Pair-wise correlations of SSB, age- 0 and age-1 juvenile densities, and recruitment of yellow perch in the western basin of Lake Erie between 1999 and 2013 showing relationships between (A) SSB in year $t$ and age-0 juvenile density in August in year $t,(B)$ age- 0 juvenile density in August in year $t$ and age-1 juvenile density in August in year $t+1$, and (C) age- 1 juvenile density in August in year $t+1$ and age- 2 recruitment in year $t+2$. All data were log transformed before analyses.

$211 \times 176 \mathrm{~mm}(72 \times 72$ DPI $)$ 


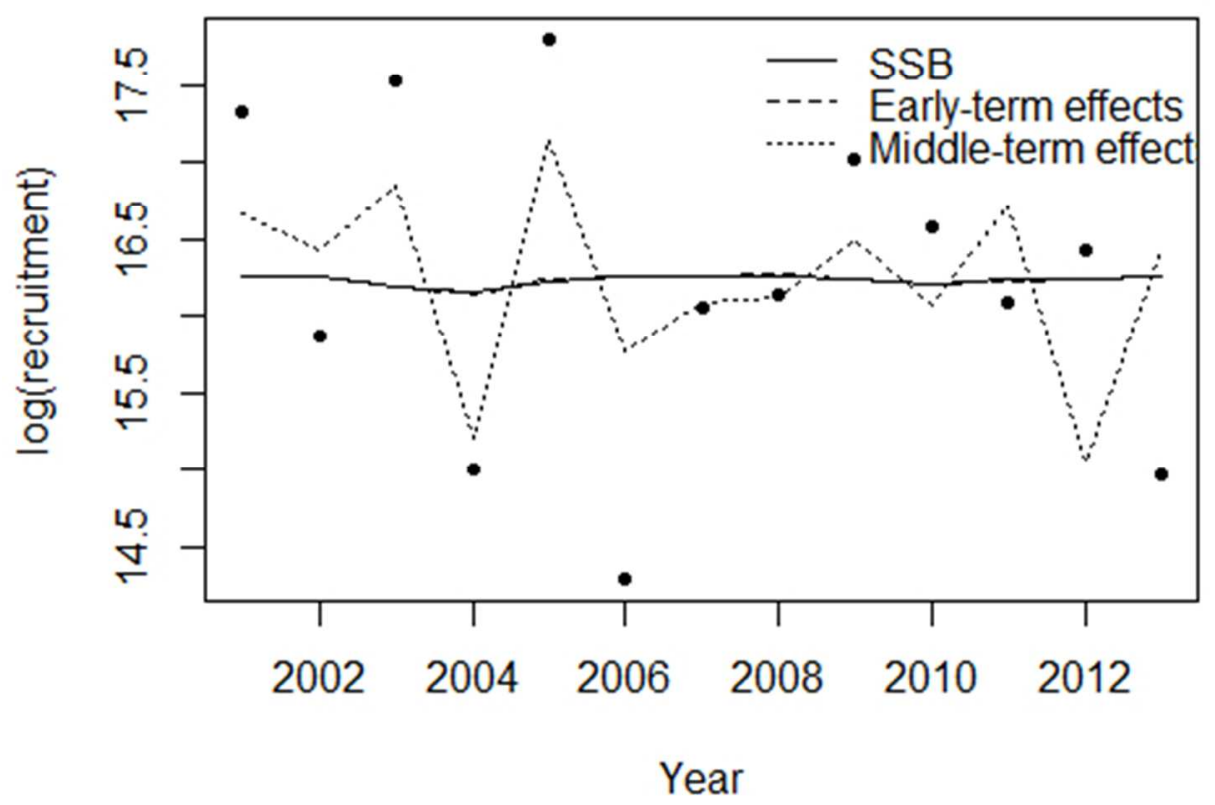

Fig. 5. Model fit of the Ricker-R models representing effects of SSB, early-term and middle-term factors on yellow perch recruitment in the western basin of Lake Erie between 2001 and 2013. The black dots are the estimates of recruitment, the solid line is the recruitment prediction by model representing effects of SSB, the dashed line is the recruitment prediction by model representing early-term effects, and the dotted line is the recruitment prediction by model representing middle-term effects.

$176 \times 141 \mathrm{~mm}(72 \times 72 \mathrm{DPI})$ 


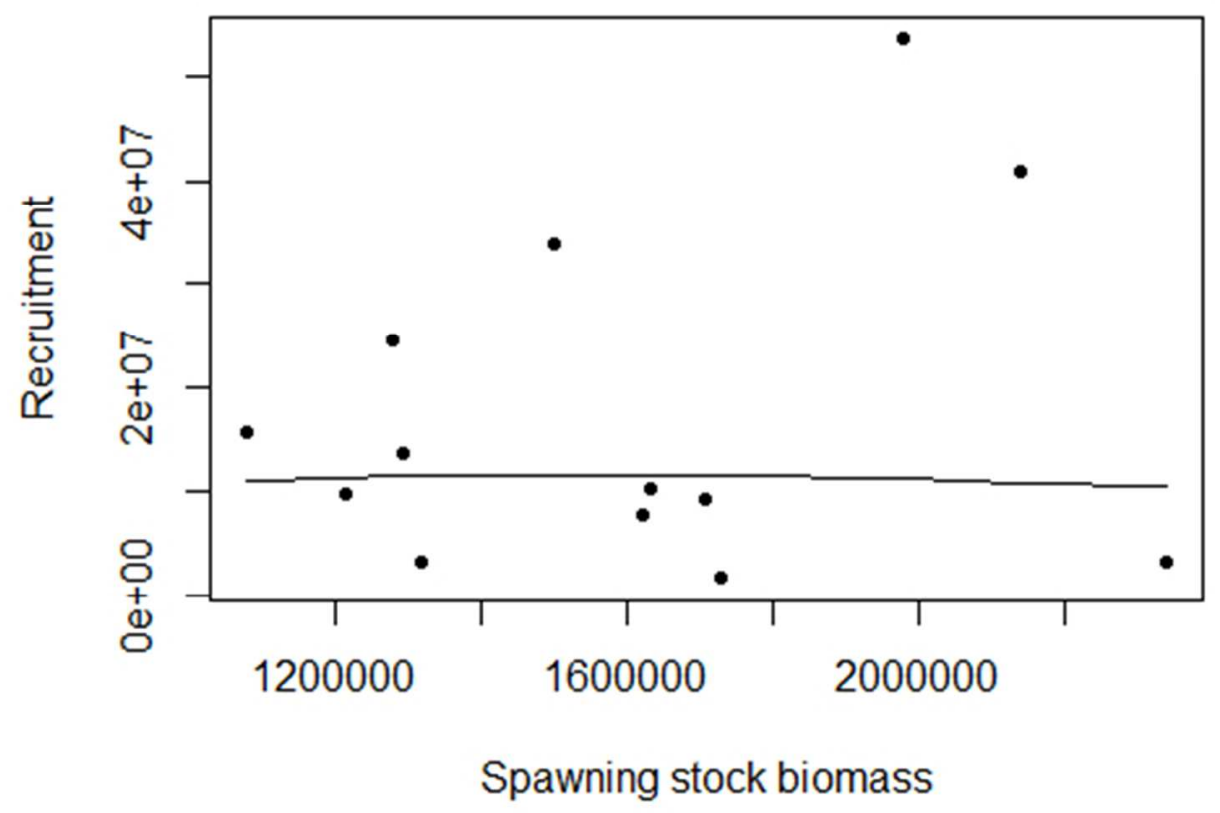

Fig. 6. Model fit of Ricker model to the observed stock-recruitment dynamic. The black dots are the estimates of SSB and recruitment, and the solid line is the prediction by Ricker model.

$176 \times 141 \mathrm{~mm}(72 \times 72 \mathrm{DPI})$ 